DOI: $10.31866 / 2410-1915.21 .2020 .208259$

UDC 75.034:7.041.5(450)

\title{
SIMONETTA VESPUCCI IN THE MIRROR OF RENAISSANCE ART: IMAGE OR ART IMAGE?
}

\author{
Rada Mykhailova
}

Doctor of Art Studies, Professor, ORCID:0000-0002-7264-0205, radami1818@gmail.com, Kyiv National University of Technologies and Design, 2, Nemyrovycha-Danchenka, St., Kyiv, 01011, Ukraine

\section{For citations:}

Mykhailova, R. (2020). Simonetta Vespucci in the Mirror of Renaissance Art: Image or Art Image? Culture and Arts in the Modern World, 21, 220-230. https://doi.org/10.31866/2410-1915.21.2020.208259.

This article deals with the portraits of the Florentine court lady of the $15^{\text {th }}$ century Simonetta Vespucci. The analysis of the content and meaning of the works of one of the prominent Renaissance artists Sandro Botticelli was conducted on the basis of the study of image methods and particular artistic approaches to the model characteristic.

To study the artist's paintings - portrait and genre - cultural and art studying analysis was used, in particular, a comprehensive examination of the material (hairstyle and accessories) and nonmaterial (ideas and art image) levels of Simonetta Vespucci's representation as a historical figure and mythological character. The purpose of the article is to reveal in the portrayals of Simonetta Vespucci the signs of art image and image, which provide portraits with different meaning. The research novelty of the article is the interpretation of the hairstyle, clothing, jewellery - as a means of creation in one case typified artistic image, mythical character, in another - the image of a noble court lady, of upper-class woman. The study makes it possible to summarize the historical experience as to modern art image creation and image-making, to understand the mechanisms of introducing this historical experience into the practice of contemporary design.

Conclusions. Due to systematic visualization of Simonetta Vespucci's images, her portraits of the Renaissance period embody different sense characteristics. The underlined details of hairstyles, clothing, accessories in the artist's portraits $(1475,1475-1480)$ create the idea of Simonetta as a real person, a noble Florentine woman, court lady, whose image corresponds to the idea of representation of the upper class of Italian society in the fifteenth century. Symbolism and convention of accessories and hairstyles, as well as bringing the image of Simonetta Vespucci to the formula of God-man in line with ancient traditions in the paintings "Primavera", "The Birth of Venus", "Venus and Mars", corresponds to the idea of typification, artistic image, image-ideal in the spirit of myth-creation in the Renaissance period.

Keywords: Renaissance painting; art image; image; hairstyle; accessories; Simonetta Vespucci; Sandro Botticelli.

(c) Rada Mykhailova, 2020 


\section{Introduction}

Image and art image belong to the priority concepts of the contemporary design (Mykhailova \& Kostiuchenko, 2018; Mykhailova \& Koropenko, 2018; Mykhailova \& Fedorova, 2016). According to the recent research the notion of "art image" tends to the definition of order, method and organization that by content corresponds to the reflection, imagination and provides stable forms of human activity: the peculiarities of communication, behaviour, a way of thinking; strictly speaking, "art image" has the meaning of the result of the world reflection in the man's consciousness (feeling, imagination, notion, idea). On the other hand, this notion has a stable form in the word combination "artistic image", which belongs to the universal category of creative work, form of interpretation and exploration of the world from the point of view of artistic ideal, typification, and creative transformation of the reality in the form of generalization for content comprehensiveness. Image combines the real features of the object and non-existent, fictitious qualities, created by public relations, propaganda, advertising to form in mass consciousness the certain attitude to the object. The notion of "image" includes combined ideas formed in public opinion as to the way how a person should look, think, behave according to his status, and how his status rights should be declared.

In correlation image - art image the sense loading of the notion "art" image corresponds to the "inner" state of the individual and "image" to his exterior manifestation. Image embodies the thought of rational and emotional character about the object (men, subject, system). It is more superficial, diverse, rapidly changing, suits to fashion, historic moment, etc. The art image responds to the fundamental natural principals - psychotype, character and temper of the individual. It is changing not by the abrupt transformation but by the long evolution method, by inner development of the personality, its vital accumulation, qualitative changes. Image and art image may coincide in human individual and works of art - the original "epoch documents" - in particular demonstrate it. For example, paintings with portrait representation of Simonetta Vespucci.

Creative work of Sandro Botticelli (Alessandro di Mariano di Vanni Filipepi, 1445-1510) is the subject of interest of many researches. In 2014 the conference devoted to his activity was performed in London. This event not only brought together scientists from different countries but also revealed the problematic directions as to Botticelli. Thus Diane Kunzelman made technical investigation of artist's works; Alessandro Cecchi - the collection of paintings from the Palatine gallery; Maria Cristina Rodeschini - the results of restoration of master's works in the Accademia Carrara in Bergamo; Hans Korner - artist's creative and economic strategy; O’Malley - the demand for Botticelli after 1490; Roberta J. M. Olson - iconography of "The Madonna of the Magnificat" and its serial replications; Francesca Migliorini - Botticelli's illustrations for Dante's works; Jonathan Nelson - Botticelli's "Virile Air": Reconsidering the Milan Memo of 1943; Gert Jan van der Sman - life and career of the painter; Laura Refe - the influence of ancient times on the creative work of Botticelli in Florance. In the context of the given research, the article "The Vespucci family and Sandro Botticelli: Friendship 
and patronage in the Gonfalone Unicorno» by Irene Mariani is the most important. It is devoted to the family history of his favourite model Simonetta (Horne, 1908). The phenomenon of the popularity of Simonetta is confirmed by historic facts and by the topic of the C. Angelini's work (Angelini, 2007).

The portraits of the Florence beauty Simonetta Vespucci by Sandro Botticelli belong to the most mentioned in the works devoted to the evolution and new design of hairstyle (Asser, 1966), and that, considering the stable interest to the history of hairstyle (Sherrow, 2019), is becoming increasingly important. In particular, $\mathrm{PhD}$ student from Kent State University Yun-Tin Se investigated hairstyle in the period of the Renaissance (Hsieh, 2003).

Regarded as an example of hairdressing skills, the Botticelli's Renaissance hairstyles to some extant do not correspond to the common ideas of their use, therefore they receive another "image creative" sense in painting. At the same time the contemporary development of design in particular such part of it as image creation actualize subject-technological and content meanings of hairstyles which are currently understood as purposeful creations of the characteristics of a person. So hairstyles, garment and accessories on the portraits of "beautiful Simonetta" give the reason to analyse her portrayal from the point of view of the image-idea and idea-art image, and that is the purpose and the task of this article.

\section{Purpose of the article}

The purpose of the article is to reveal the signs of art image and image in the portrayal of Simonetta Vespucci by means of painting on the example of works by Sandro Botticelli.

Historical and cultural methods were used to study the artist's paintings portrait and genre painting. Due to these methods, the level of development of the Renaissance art at the Court of Cosimo de'Medici was revealed. To examine the portraits of Sandro Botticelli the following art studying methods were used: stylistic analysis, biographical analysis, plot-compositional construction.

\section{Main research material}

The history of Simonetta Cattaneo-Vespucci - the first lady at the Florentine court of Lorenzo de'Medici, La Sans Pareille - "incomparable" or La Bella Simonetta - "beautiful Simonetta" - phenomenon of the Renaissance and modern time, since the quantity of her portraits in modern advertising is not less than the Mona Lisa of Leonardo da Vinci. Married at 16 with Marco Vespuc$\mathrm{ci}$, the relative of the famous sailor and discoverer of America Amerigo Vespucci, not only she did return her family from the forced exile but also became in the focus of attention of the Florentine court of Lorenzo de'Medici. Simonetta became the beloved woman of the "Prince of Youth" Giuliano de'Medici, the brother of Lorenzo, whose death at the age of 24 from dagger of enemies became the general tragedy. Simonetta was also destined to live a short life - only 23 years. 
The noble and exquisite Simonetta Vespucci considered to be the standard of beauty. Red-haired, with white skin and blue eyes, she was a model of several Italian masters of trecento and quattrocento. Besides works by Sandro Botticelli, she was recognized in the works of Piero di Cosimo and sometimes Giovanni Bellini. And if Piero di Cosimo described her as Cleopatra (Waldman, 2000), Bellini - as the Virgin Mary, and Botticelli - as the "universal" heroine of ancient and biblical myths. His works "The Birth of Venus" (around 1485), "Primavera" (around 1478), "Venus and Mars" (1483), "Madonna and Child" (1470) "The Madonna of the Book" (1483), "The Madonna of the Pomegranate" (1487), depict a woman with the same facial features. Simonetta's features are also seen in the sculptural portrait of Andrea del Verrocchio.

Botticelli created a number of portraits where Siminetta appears full of "charm and melancholy" (Dmitrieva, 1968, p. 31). Thus, a portrait of 1480 (1476?) from Berlin Picture Gallery shows Simonetta Vespucci in profile on the background of the window through which the blue sky is seen. Rays of sun light up fiery sparks of the golden hair which is distinctly shaded by the black velvet and the cold reddish silk of the dress resembling "stained-glass" combination of colours. With particular care Botticelli depicts the hairstyle of the beauty, the basic of which is waving hair put into the bun arranged just below the back of the head. Forehead, cheek bones and chin are framed by thin strands cut as "cascade" hairstyle. They form three levels of light volume around the face. Freely "loose" curls add lightness and elegance to the hairstyle. The bulkiest strands with the curl at the end is laid out by the long snake-like loop over the ear and the loose end of it is brought out of the bun on the back of the head and then falls to the shoulders. Tightly braided plait, which imitates the ribbon with pearls in it, overlays the strand and the bun. The plait is wrapped around the bun and holds a large "snake-like" strand and then goes out from under the loop of the large strand and under right angle falls down, forming an additional "pearl" decor. Flat decorative cord also weaves the wave of hair on the back three times crosswise. Four large pearls placed on the parting line decorate the forehead and upper part of the head. The hairstyle is fastened with thin double black cords which girdle the head and the plait of the bun and come out under the chin. According to experts, this method was often used in the Middle Ages, it was called "barbet". Flat strand under the chin, for example, characterizes Cecilia Gallerani's hairstyle in the portrait of Leonardo da Vinci (1490). As for Simonetta's hairstyle, the transparent veil on her hair supported by the cord is rather imitation of barbet or the new ways of fixing such hairstyle, because at the time of the fifteenth-century European hairdressing used enough hairstyling skills.

On the "Portrait of a Young Woman" (1475-1480) she was depicted in profile in a white silk dress. The face of the beauty is turned to the right unlike the previous portrait, where the face is positioned to the left. Her rich white tunic-like draped dress shades the gorgeous, light skin of the face. Against the black background of the portrait which contrasts with Simonetta's light outfit, the golden hair in a disobedient hairstyle looks particularly striking. It is a cascade of curled strands on the cheekbones and neck and three small plaits, which are arranged on the sides of the head, tied into knots crosswise. The larg- 
est knot - on the top of the head, which is a kind of "ponytail". It is formed by the ribbon-like plait that surrounds the head like a frontlet. Long plait-cords, fastened in the hair imperceptibly, descend on both sides of the shoulders and then - on the chest as gold chain of the pendant. The similarity with the pendant is achieved in the following way: plaits are brought together and fixed by a ring. Decor of plaits is generously decorated by pearls. Five large pearls are located along the parting. On the top of the head, they make a composition with lily-shaped brooch, which is agraffe with white feather. Three strings of pearl beads are fastened on the three decorative plaits with knots. On the top of the head pearls are combined with the red ribbon that wraps the hair with rings and in the lower part of the head - crosswise. Pearls suit well to the neck decoration - a cameo of dark colour in the gold frame in the form of a set of chains. The dress, jewellery and hairstyle are designed to emphasize the almost royal position of Simonetta.

Therefore, the variety of her hairstyles was achieved by means of haircut, waving on paper curls. Hairdressers if necessary also used colouring: Italians appreciated the shades of honey and wheat, chestnut and reddish, which is called "titian". It was achieved by soaking the hair in acids or onion peels, followed by drying in the sun. The golden hair that Simonetta had probably by nature was especially valued. The fashionable at that time high forehead was made by shaving over the hairline. Artificial plaits were used to decorate hairstyles, they were placed into white silk case, wrapped with ribbon crosswise. The hair was styled with decorative plaits and cords, knots, "tassels", loose strands, waves. Artificial materials were added to the decor - ribbons, cords, jewellery, for example, brooch - frontlets. Complex hairstyles were the combination of plaits, curls, pearl necklaces, jewellery, veils, combined into creative, fancy compositions. Hairstyles were made in several stages: preparation of hair (washing), formation of the parting distribution zone, cutting, drying, fluffing, curling, backcombing, fixing. The creation of the hairstyle took several hours.

Thus, the hairstyle during the Renaissance is an expression of social status. The hairstyles that Botticelli reproduced on the canvases corresponded to the aesthetic tastes of representatives of the Italian nobility of large cultural centres: Milan, Venice, Genoa (Tkachenko, 1999; Asser, 1966; Sherrow, 2019; Hsieh, 2003). Thoroughly arranged Simonetta's hair, velvet and silk dresses, jewellery, accessories demonstrate that she belongs to the wealthy family living in palaces surrounding by riches.

Simonetta's art image was also introduced into the works on the theme of antiquity that embodies the world of Greek mythology. These are the pictures "Primavera" (1482, Primavera) and "The Birth of Venus" (1485, Nascita di Venere), which are in the Uffizi Gallery in Florence. The first work is based on Roman literature and poetry of the Renaissance: episodes of "The Fasti" by Ovid, the odes of Horace, lines of "The Aeneid" by Virgil, the poem "On the Nature of Things" by Lucretius, as well as literary pieces written by Leon Battista Alberti and Angelo Poliziano. The main feature of the compositional decision of "Primavera" is that the art image of golden-haired Simonetta is repeated several times: six heroines have her features. It is Spring itself and also the goddess 
of flowers Flora (Chloris), who drops roses, and goddess of love, patroness of gardens Venus, who is surrounded by aureole from myrtle leaves. There are also three Graces (Charites) dancing hand in hand - Aglaea (Shining), Euphrosyne (Good Cheer) and Thalia (Blooming).

The variety of character types of his favourite model Botticelli achieves with the help of hairstyle, which he enthusiastically invents to describe her. Thus, the Venus hairstyle is light rings of golden hair that protrude from beneath the cover. Flora's hairstyle is a freely fallen "cascade" cut hair, wide strands of which at different levels frame the face with locks. On Flora's head there is a wreath of blue, white and yellow wildflowers laid out as diadem. Floral fastenings on temples support capricious curls. Flora, who is pursued by Zephyr, has simple and casual hairstyle as the hair, combed out backwards, is weaved by strings of pearls on the neck.

The hairstyles of three Graces, which appear as heathen tsarevnas, look more complicated. The hair colour of three beauties tends to one golden tone but has light and dark shades. Aglaea who stands near Hesiod-Mercury has the hairstyle made up of bulky strands placed over the forehead and back of the head, and then curls intertwined crosswise with the "cord" made of hair. The separate part of hair in looped form gives accent to the beautiful shape of the ear. A large pearl fastened to the back of the head completes the symmetry of the hairstyle and from the point of view of composition goes well with a round brooch in the form of a flower with pointed petals and large pearls on the transparent garment of goddess.

Another Grace - Euphrosyne has the hairstyle made of small curls, which on both sides symmetrically decorate the head, covering the ears. Behind them the bulk of the hair intertwined with thin cordlike strands. In some places the hair is tightened with knots, the distance between them is formed with volume and shape. Decorative plait between the temples imitates a hoop. Back of the hairstyle is in the form of "lapping" of large curls which add to the hairstyle volume and capriciousness. The rest of the hair that falls on the back as a "tail" is divided by the knots due to which the "tail" is separated into several parts. The lower part is voluminous and spherical, ending with a lush S-shaped curl.

The hair of the last Grace Thalia has light golden shade. Her hairstyle is formed by the principle of symmetric composition from the small wave curls lowered on both sides of the face. They a little bit cover cheeks creating a beautiful light volume. The longest part of the hair formed into the fluffy mass is like a stream that "flows down" to the shoulders. The decoration of the hairstyle is a pearl diadem, round curls of which are tucked into the strands of the temporal part, goes to the back of the head as if a crown-diadem. This diadem stylistically corresponds to the pearl necklace that decorates the girl's neck. The symbolism of pearls, which has a shade of eroticism, is a hidden hint of the element of love embodied by the youth. Italian women believed that jewellery with pearls helps to preserve beauty. At the same time, pearls were attributed the symbolism of tears and sadness and it is possible that in the painting they symbolize the early death of Simonetta. It is known, for example, that at the end of the $16^{\text {th }}$ century the symbolism of pearls was associated with the image of Virgin as a sign 
of sorrow, cleanliness and purity. Simonetta's pearl jewellery is the tribute of time. In the $16^{\text {th }}$ century peals came into Western European fashion. They were represented as luxury item in paintings of Italy, France, the Netherlands, Germany, and Spain. From the end of the Middle Ages, pearls competed with precious stones and at the end of the Renaissance became the manifestation of the aesthetics of Mannerism with its attraction to asymmetry and capriciousness. At that time about 120 shades of white, pink, golden, black, blue, bronze colours of pearls were known (Crowe, 2008).

Pearls were also associated with the image of Aphrodite-Venus, who according to the legend came out from the sea foam. In the art image of the goddess of beauty Simonetta Vespucci appears in the monumental mythological painting “The Birth of Venus" (tempera, canvas, 172,5 × 278,5). Simonetta who claimed that she had been born in Portovenere, ${ }^{1}$ probably was associated with Greek goddess.

The content of the story, popular at the Medici court where the representatives of Florentine intellectual elite gathered, revealed a poem by the poet Angelo Poliziano (1454-1494), who described the birth of Venus from the sea deep by the coast of Cyprus. It is noteworthy, however, that the meaning of the poem was the theme of Heavenly Venus - humane, merciful, whose love and beauty were the pledge of mortals in heaven. This doctrine of beauty was proclaimed by philosophy Marsilio Ficino (1433-1499) who sought a combination of classical philosophy and Christianity. Therefore, his Venus is the embodiment of the features of the Virgin Mary. For Botticelli, Simonetta-Venus even marked with the features of Christianity, refers rather to the image of Eve, in the way we will see her later in Cranach and Durer's canvases. In Botticelli's paintings she is nude like an ancient sculpture. Hairstyle is her only garment. The fluffy long golden hair of Venus is blown by the warm wind of Zephyr; it is divided into large strands and curls interlaced with one another, each ending by a tight spiral. Most of the hair that falls on Venus's back is decorated with a blue ribbon on the neck. Several small curls around her face give tenderness and to some extant neutralize the involuntary association of the hairstyle of Venus-Simonetta with snakes swirling around like that of Medusa Gorgon (Dmitrieva, 1968, p. 277).

In the mythological paintings of Botticelli Simonetta Vespucci becomes an ancient goddess. Her art image embodies the divine beginning in the earthly human form. The main element of the image is a hairstyle - fluffy, royal and at the same time free, relaxed, "heathen". The adjustment of the features of Simonetta Vespucci's appearance to the ancient standard of beauty on the basis of generalization and typification of the art image responds to the idea of the divine image what emerges from the real and natural world on the principle of selectivity and idealization.

\section{Conclusions}

The portraits of Simonetta Vespucci created by Sandro Botticelli illustrate the variety of solutions of different artistic issues, the keynote of which is the

${ }^{1}$ According to another version she was born in Genoa. 
harmonization of two-dimensional formula image - art image. For its realisation, the great master turns to specific image-compositional constructions and approaches in characteristics of a model by focusing on accessories and hairstyle. Hairstyle is a product of hairdressing, the result of consistent and methodical, technical and technological actions of hair styling according to a certain idea, system, plan, is one of the greatest heritage of human culture, which finds a peculiar conformation in the creative work of Botticelli. During centuries the process of hairstyle creation has transformed an ordinary person into personality, a person-representative of a certain social status, the carrier of a specific outlook and image. In the works of Sandro Botticelli it is an instrument of personification of courtly, secular culture and court etiquette. In this sense, the way Botticelli depicts Simonetta Vespucci corresponds to the definition of a representative of the upper class of society, court lady and "beautiful lady".

Another "layer" of Simonetta Vespucci's depiction is the features that generalize her art image, elevate it to the level of eminence beyond life being. In antique plots Botticelli elevates Simonetta's art image to the level of Godman transforming a real woman into a deity, a standard, a model of "divine beauty".

The reflection of Simonetta Vespucci in the mirror of Renaissance art, the combination in one person of the image of court lady and timeless art image of a God-man - is the historical example of the deep meaning of this phenomenon that has its continuation in our time.

\section{References}

Angelini, C. (2007). The mystery of Simonetta (M. King, Trans.). Guernica [in English]. Asser, J. (1966). Historic hairdressing. Pitman [in English].

Crowe, J. (2008). Spravochnik dlia iuvelirov. Rukovodstvo po otcenke $i$ ispolzovaniiu dragotcennykh kamnei [Reference book for jewelers. Guidance on the evaluation and use of gemstones]. Art-rodnik [in Russian].

Dmitrieva, N. (1968). Kratkaia istoriia iskusstv. Ocherki [brief history of art. Essays] (Issue 1). Iskusstvo [in Russian].

Horne, H. P. (1908). Alessandro Filipepi, commonly called Sandro Botticelly. G. Bell \& sons [in English].

Hsieh, Y.-T. (2003). Coiffure in Renaissance Italy: divine beauty versus worldy achievement. M.A. Kent State University [in English].

Mykhailova, R. D., \& Fedorova, Ye. V. (2016). Pro zmist ta spivvidnoshennia poniat "obraz" ta "imidzh" [About content and correlation of concepts "character" and "image"]. Bulletin of KNUKiM. Series in Arts, 35, 206-217. https://doi. org/10.31866/2410-1176.35.2016.158260 [in Ukrainian].

Mykhailova, R. D., \& Koropenko, M. V. (2018). Tema ta obraz v dyzainerskii diialnosti Teo Voziianova [Theme and image in the design activity of Theo Vozianov]. Bulletin of KNUKiM. Series in Arts, 38, 237-249. https://doi.org/10.31866/24101176.38.2018.141826 [in Ukrainian].

Mykhailova, R. D., \& Kostiuchenko, O. M. (2018). Styl odiahu ta yoho rol u formuvanni imidzhu [Clothing style and its role in image formation]. Culture and Arts in the 
Modern World, 19, 98-110. https://doi.org/10.31866/2410-1915.19.2018.141361 [in Ukrainian].

Sherrow, V. (2019). Encyclopedia of Hair: A Cultural History. Greenwood [in English].

Sman, G. J. van der, \& Mariani, I. (Eds). (2014). Sandro Botticelli (1445-1510): Artist and entrepreneur in Renaissance Florence, Proceedings of the International Conference held at the Dutch University Institute for Art History, Florence, 20-21 June 2014. Centro Di [in English].

Tkachenko, L. P. (1999). Moda yak estetychnyi fenomen [Fashion as an aesthetic phenomenon]. (Abstract of $\mathrm{PhD}$ Dissertation). H. Skovoroda Institute of Philosophy, Kyiv [in Ukrainian].

Vanderzant, M. W. (1983). Piero di Cosimo's Simonetta Vespucci: a fantasy portrait. Ann Arbor [in Italian].

Waldman, L. A. (2000). Fact, Fiction, Hearsay: Notes on Vasari's Life of Piero di Cosimo. The Art Bulletin, 82, 1, 171-179. https://doi.org/10.2307/3051370 [in English].

\section{СИМОНЕТТА ВЕСПУЧЧІ У ДЗЕРКАЛІ РЕНЕСАНСНОГО ЖИВОПИСУ: ОБРАЗ ЧИ ІМІДЖ?}

\section{Михайлова Рада Дмитрівна}

Доктор мистецтвознавства, професор, ORCID: 0000-0002-7264-0205, radami1818@gmail.com, Київський національний університет технологій та дизайну, Київ, Україна

У статті розглянуто портретні зображення флорентійської придворної дами XV ст. Симонетти Веспуччі. На основі дослідження способів зображення та специфічних художніх підходів до характеристики моделі проаналізовано змістовно-сенсові аспекти робіт одного з видатних митців Відродження Сандро Боттічеллі.

Для вивчення живописних творів митця - портретних та сюжетних - застосовано культурологічно-мистецтвознавчий аналіз, зокрема комплексний розгляд матеріальних (зачіска та аксесуари) і нематеріальних (ідейно-образних) рівнів презентації Симонетти Веспуччі як історичної особи та міфологічного персонажа. Метою статті є виявлення у її зображеннях ознак іміджу та художнього образу, що надає портретним відтворенням різного сенсового наповнення. Наукова новизна роботи полягає в інтерпретації зачіски, одягу, прикрас - як засобів створення в одному випадку типізованого художнього образу, міфічного персонажа, в іншому - іміджу знатної придворної дами, жінки вищих прошарків суспільства. Дослідження дозволяє узагальнити історичний досвід щодо модерного образотворення та іміджетворення, зрозуміти механізми впровадження даного історичного досвіду в практику сучасного дизайну.

Висновки. Завдяки системно продуманій візуалізації зображень Симонетти Веспуччі ї̈ портрети доби Відродження втілюють різні сенсові характеристики. Підкреслені митцем деталі зачіски, одягу, аксесуарів на портретах 1475 р. та 
1475-1480 рр. створюють уявлення про неї як реальну особу, знатну флорентійку, придворну даму, імідж якої відповідає ідеї представництва вищих прошарків італійського суспільства XV ст. Символізм та умовність аксесуарів та зачіски, а також приведення зображення Симонетти Веспуччі до формули людинобожжя в дусі античних традицій у картинах «Весна», «Народження Венери», «Венера і Марс» відповідають ідеї типізації, художнього образу, образу-ідеалу в дусі міфотворчості доби Відродження.

Ключові слова: ренесансний живопис; образ; імідж; зачіска; аксесуари; Симонетта Веспуччі; Сандро Боттічеллі.

\section{СИМОНЕТТА ВЕСПУЧЧИ В ЗЕРКАЛЕ РЕНЕССАНСНОЙ ЖИВОПИСИ: ОБРАЗ ИЛИ ИМИДЖ?}

\section{Михайлова Рада Дмитриевна}

Доктор искусствоведения, профессор, ORCID: 0000-0002-7264-0205, radami1818@gmail.com, Киевский национальный университет технологий и дизайна, Киев, Украина

В статье рассмотрены портретные изображения флорентийской придворной дамы XV в. Симонетты Веспуччи. На основе исследования способов изображения и специфических художественных подходов к характеристике модели проанализированы содержательно-смысловые аспекты работ одного из выдающихся художников Возрождения Сандро Боттичелли.

Для изучения живописных произведений художника - портретных и сюжетных - использован культурологически-искусствоведческий анализ, в частности, комплексное рассмотрение материальных (прическа и аксессуары) и нематериальных (идейно-образные) уровней презентации Симонетты Веспуччи как исторической особы и мифологического персонажа. Цель статьи - выявить в ее изображениях признаки имиджа и художественного образа, которые придают портретным изображениям разное смысловое наполнение. Научная новизна работы состоит в интерпретации прически, одежды, украшений - как средств создания, в одном случае, типизированного художественного образа, мифического персонажа, в другом - имиджа знатной придворной дамы, женщины из высших слоев общества. Исследование позволяет обобщить исторический опыт относительно модерного создания образа и имиджа, понять механизмы внедрения данного исторического опыта в практику современного дизайна. Выводы. Благодаря системно продуманной визуализации изображений Симонетты Веспуччи ее портреты эпохи Возрождения воплощают разные смысловые характеристики. Подчеркнутые художником детали прически, одежды, аксессуаров на портретах 1475 г. и 1475-1480 гг. создают представление о ней как о реальной особе, знатной флорентийке, придворной даме, имидж которой отвечает идее представительства высших слоев итальянского общества XV в. Символизм и условность аксессуаров и прически, а также приведение изображений Симонетты Веспуччи к формуле человекобожия в духе античных 
традиций в картинах «Весна», «Рождение Венеры», «Венера и Марс» отвечают идее типизации, художественного образа, образа-идеала в духе мифотворчества эпохи Возрождения.

Ключевые слова: ренессансная живопись; образ; имидж, прическа; аксессуары; Симонетта Веспуччи; Сандро Боттичелли. 